Niepełnosprawność. Dyskursy pedagogiki specjalnej

Iwona Myśliwczyk

Uniwersytet Warmińsko-Mazurski w Olsztynie

\title{
Dorosłe osoby z niepełnosprawnością intelektualną - (nie)możliwe zmiany w ich sytuacji rodzinnej
}

\begin{abstract}
Dorosłość osób niepełnosprawnych intelektualnie, to wciąż obszar ciągłych polemik. Tekst ten jest próbą odpowiedzi na pytanie jak interpretują własną dorosłość osoby z niepełnosprawnością intelektualną, które mieszkają ze swoimi rodzicami. Niekiedy bowiem to najbliższa rodzina - jak pokazują narracje - jest tym środowiskiem, które ogranicza wejście w tę dorosłość i nie pozwala na osiągnięcie autonomii. Rodzice często nie zdają sobie sprawy, że ich dorosłym niepełnosprawnym intelektualnie dzieciom, którym nie pozwoli się na osiągnięcie statusu człowieka dorosłego, pozostaje opieka instytucjonalna lub samotne życie wśród pełnosprawnych.
\end{abstract}

Słowa kluczowe: dorosłość, niepełnosprawność intelektualna, rodzina

\section{Adult people with intellectual disabilities - (im)possible changes within family situation}

Adulthood of people with intellectual disability persistently remains the area of polemics. The article attempts to answer how adult people with intellectual disabilities, who have been living in their family homes, describe adulthood. Their narratives revealed the families sometimes restrict to facilitate a successful passage into adulthood and establishing autonomy. Parents are often unaware their adult children, if not allowed the transition into adulthood, remain condemned to live their live in institutions or experience loneliness among able - bodied.

Keywords: adulthood, intellectual disability, family

\section{Dorosłość osób niepełnosprawnych}

Pojęcie „człowiek dorosły” jest bardzo trudne do zdefiniowania, bowiem różne definicje ujmują różne aspekty, co oznacza, że można je rozpatrywać z perspektywy uwarunkowań biologicznych lub z perspektywy zależności kulturowych, społecznych czy indywidualnych [Pichalski 2003, s. 79-80]. W literaturze można znaleźć wiele określeń człowieka znajdującego się w tej fazie rozwoju, a różnica między nimi wynika z odmiennego rozumienia pojęcia i jego zakresu. Ponadto 
trzeba pamiętać, że zmieniają się też schematy pojęciowe w nauce, co przyczynia się do wielości perspektyw widzenia kategorii „dorosłości” i co nastręcza pewną trudność w ustrukturyzowaniu wiedzy na ten temat [tamże].

Dorosłość jest tą kategorią, którą można rozpatrywać w wielu wymiarach, które wciąż się zmieniają. E. Garlej-Drzewiecka na określenie tej trudnej, złożonej i wielopłaszczyznowej sytuacji w odniesieniu do kategorii dorosłość, używa określenia „paradygmat otwarty” (2003, s. 85), co może oznaczać trudność w zamknięciu dorosłości w pewne ramy czy niezmienne kryteria. Według autorki nadal jest to niesprecyzowane zjawisko i u każdego przebiega w sposób indywidualny. Chcąc zobaczyć, jak kształtuje się proces dorosłości, należy skoncentrować się na indywidualnej drodze rozwoju każdego dorosłego, na biegu jego życia, który układa się w kontinuum [tamże, s. 86].

Współczesność i dorosłość $\mathrm{w}$ nią wkomponowana powoduje, że A. Brzezińska i inni [2008, s. 262-263] dostrzegają pewne trudności w uchwyceniu „momentu w którym jednostka staje się dorosła. Istota bycia dorosłym zasadza się bowiem nie na osiągnięciu określonego wieku metrykalnego, lecz na podjęciu zobowiązań w pewnych obszarach aktywności i na trwaniu w ich realizacji pomimo przeszkód fizycznych, społecznych czy psychologicznych. Potencjał dorosłości $\mathrm{w}$ przeciwieństwie do poprzedniego stadium rozwoju - tkwi nie tyle $\mathrm{w}$ umiejętności podejmowania wyzwań, ile w realistycznym budowaniu wizji przyszłości, stawiania celów ambitnych, ale możliwych do osiągnięcia i braniu odpowiedzialności za efekty swoich autonomicznych wyborów" [tamże]. Lista atrybutów dorosłości obejmuje "nieustawanie w działaniach, akceptowanie swoich granic, umiejętność relatywizowania wydarzeń, zdolność do autonomii i przeżywania samotności. Ważne jest także pełnienie podstawowych ról społecznych, umiejętność łączenia teorii z praktyką, panowanie nad emocjami, nieranienie uczuć innych osób" [Garlej-Drzewiecka 2003, s. 87].

Sens dorosłego życia ujął także B. Smykowski pisząc, iż jest to „podejmowanie i odpowiedzialne realizowanie zobowiązań wobec siebie i innych ludzi w wielu obszarach aktywności życiowej. Dorosłość oznacza więc zdolność uświadamiania sobie własnych potrzeb, wolę i możliwość brania odpowiedzialności za sposób ich zaspakajania. Oznacza to nie tylko odpowiedzialność w świetle prawa za swoje uczynki, ale przede wszystkim gotowość do samodzielnego troszczenia się o siebie i swoje sprawy" [2004, s. 4-5]. W. Szewczuk analizując dorosłość, zwrócił szczególną uwagę na kategorię samodzielności: „Człowiek staje się dorosłym, gdy jest sam odpowiedzialny za siebie, gdy jest podmiotem działalności, sam decyduje o swoim planie życiowym, sam umie się borykać z trudnościami jego realizacji, sam odpowiada wobec społeczeństwa za swą działalność" [1993, s. 123]. 
Wieloznaczność pojęcia dorosłości wymusiła dokonanie analizy tej kategorii, nad którą pochyliła się M. Kościelska [2012, s. 17]. Autorka wyodrębniła:

- dorosłość w sensie społecznym, która ma wydźwięk w sposobie bycia i zachowania charakteryzującym się dojrzałością, odpowiedzialnością, logiką działania;

- dorosłość w znaczeniu psychologicznym, która wyraża się m.in. poprzez „zdolność do abstrakcyjnego myślenia, zdolność do odraczania reakcji, panowanie nad emocjami, nieuleganie impulsom, kierowanie się uczuciami wyższymi i świadomość wartości";

- dorosłość jako kategoria prawna, „oznacza osiągnięcie w określonym wieku (...) pełni praw obywatelskich (...): do głosowania, do zawierania umów, w tym związków małżeńskich, do wyjazdów zagranicznych bez zgody rodziców, do posiadania prawa jazdy";

- dorosłość w sensie tożsamościowym, bowiem „tożsamość wyraża się w posiadaniu dowodu osobistego, a w kategoriach osobistych oznacza ona czucie się osobą dorosłą, która odpowiada za siebie i cieszy się wolnością" [tamże, s. 17-18].

Pod koniec XX wieku pedagogika specjalna pochyliła się nad dorosłymi niepełnosprawnymi. To im zaczęto poświęcać więcej miejsca wskazując jednocześnie na specyfikę ich funkcjonowania. Ustalono - zaznacza A. Krause - braki teoretyczne i praktyczne w obszarach rewalidacji dorosłych niepełnosprawnych, które stały się przyczynkiem do „opracowania drogi ku dorosłości, czyli modelu przygotowania jednostek niepełnosprawnych do dorosłego życia" [Krause 2010, s. 50-51]. Autor podkreśla wagę tego modelu, bowiem nie opiera się on o indywidualne podejście do dysfunkcji osoby niepełnosprawnej, ale odwołuje się do społecznych konsekwencji i utrudnień pochodzących z zewnątrz. Tak więc „podstawowym składnikiem tego podejścia jest normalizacja środowiska człowieka niepełnosprawnego, a więc takie przekształcenie warunków, które go otaczają, by mógł prowadzić jak najbardziej normalne życie” [tamże, s. 51].

Opracowanie powyższego modelu jest o tyle istotne, iż pomiędzy teorią a praktyką doszło do zupełnie innego ujmowania potrzeb dorosłego człowieka z niepełnosprawnością, co w konsekwencji wyznaczało różne drogi do dorosłości. Te niejednolite stanowiska nie uwzględniały potrzeb osób niepełnosprawnych, co przyczyniło się do wybiórczego postrzegania człowieka niepełnosprawnego i dorosłości, do której on dąży. Dorosłość generowana licznymi potrzebami osób o niepełnej sprawności, oraz niewydolność pomocy instytucjonalnej, przyczynia się do „porzucenia społecznego” [tamże, s. 52-53]. Wówczas osoba niepełnosprawna jest pozostawiona sama sobie, gdyż niepełnosprawność implikuje szereg ograniczeń w dorosłości. Kryteria dorosłości zostały ustanowione przez społeczeństwo i należą do nich: zdolność założenia i utrzymania rodziny, możliwość podjęcia pracy, samodzielność w podejmowaniu decyzji, zaradność życiowa itd. Wiele 
osób niepełnosprawnych nie podoła tym społecznym wymogom, szczególnie osoby z niepełnosprawnością intelektualną. Społeczny obraz przedstawia tę grupę osób jako osoby niesamodzielne, niezaradne życiowo i bezradne wobec codzienności. A. Krause używa wręcz pojęcia „,duże niepełnosprawne dzieci”, które to powstało w wyniku braku odpowiednich form ułatwiających bycie dorosłym, a jeśli już takie formy wsparcia istniały, to były one stygmatyzujące dla osób z nich korzystających [Krause 2010, s. 118].

Podobnego zdania jest B. Cytowska, która czyniąc namysł nad dorosłością osób z niepełnosprawnością pisze: „niepełnosprawni stają się przedmiotem troski, stwarza im się warunki w placówkach, w których jakby zatrzymał się czas, a oni, traktowani jak dzieci, prowadzą niefrasobliwe życie" [2012, s. 125]. Autorka w swoich rozważaniach zastanawia się na ile "takie" postępowanie wobec dorosłych ludzi o niepełnej sprawności intelektualnej, które z jednej strony uwzględnia ich funkcje intelektualne, a $\mathrm{z}$ drugiej jest niezgodne $\mathrm{z}$ „ich wiekiem, dojrzałością biologiczną, płciową i społeczną, należy do przejawów dyskryminacji; czy infantylizacja dorosłych jest ich delegitymizacją?" [tamże]. Odpowiedz zawarta w literaturze przedmiotu i poparta wieloma badaniami jest twierdząca.

Społeczne traktowanie osób z niepełnosprawnością intelektualną jest na takim samym poziomie, jak innych grup społecznych uznanych za odbiegające od społecznie respektowanych i uznawanych norm. Według B. Cytowskiej jest to wielkim nieporozumieniem ponieważ „problemy doświadczane przez tę populację powodują bowiem, że jej społeczny odbiór jest zdecydowanie gorszy. Ponadto trzeba pamiętać, że osobom z niepełnosprawnością intelektualną trudno się wypowiadać w swoim imieniu, wtedy gdy możliwe staje się zabranie głosu w walce o swoje prawa, przywileje, przeciwko dyskryminacji o różnych obliczach" [2012, s. 117].

Na bazie przeprowadzonych badań i potocznych doświadczeń T. Żółkowska [2003, s. 248-250] stwierdza, iż dorosłość osób o niepełnej sprawności intelektualnej jest przez środowisko „zniekształcona, lekceważona, ograniczana, tłumiona”. Takie podejście pełnosprawnych zaburza prawidłowe funkcjonowanie społeczne osób niepełnosprawnych intelektualnie, jednocześnie obniża ich potencjał rozwojowy. Przestrzeń życiowa i kreatywność osób o niepełnej sprawności intelektualnej jest ograniczana przez pełnosprawnych, co skutkuje ograniczeniami w zakresie dokonywania wyborów czy rozwijania samodzielności [tamże]. Rehabilitacja dorosłych w zdecydowanej większości przyjmuje charakter segregacyjny np. „pracy w formie terapii, monotonnej, mało twórczej, a przede wszystkim niewynagradzanej". Dorośli niepełnosprawni często mieszkają z rodzicami, bądź przebywają w instytucjach. W obu przypadkach tracą swoją podmiotowość i są traktowani jak potrzebujący ciągłej opieki i wsparcia. W wyniku specyfiki wyglądu i sposobu funkcjonowania odbiera się im prawo do pełnienia ról społecznych 
przypisanych dorosłym, i wytycza się role, które w ogóle mogą realizować. Zniekształcony wizerunek osób niepełnosprawnych intelektualnie skutkuje biernością tych osób oraz poczuciem braku wpływu na własne życie [tamże].

Udział w życiu rodzinnym dorosłych o niepełnej sprawności jest ograniczony nie tylko przez postawę społeczeństwa wobec tej grypy osób, ale także ze względu na stosunek rodziców do niepełnosprawnego dorosłego dziecka. A. Krause [2010, s. 122] pisze o infantylizacji $\mathrm{w}$ tym zakresie wynikającej z trudności rodziców w akceptacji i realizacji potrzeb dorastającego dziecka. Autor [Krause 2016, s. 12] analizując badania $\mathrm{w}$ zakresie dorosłości osób z niepełnosprawnością intelektualną [Gajdzica 2013; Kijak 2016; Zakrzewska-Manterys 2010] stwierdza, iż „w Polsce pomimo ideologicznych, teoretycznych, metodycznych i politycznych deklaracji na temat zapewnienia osobie niepełnosprawnej warunków do normalnego funkcjonowania mamy do czynienia z systemowym i społecznym upośledzaniem dorosłości osób niepełnosprawnych”. Autor podaje źródła tej „upośledzonej dorosłości", do których zalicza m.in. rodziców osób niepełnosprawnych [tamże]. Dodatkową trudnością jest brak wsparcia społecznego w uzyskaniu samodzielności przez niepełnosprawną młodzież oraz oczekiwania wobec rodziców ze strony społeczeństwa. Te oczekiwania wymuszają na rodzicach opiekuńczość, troskę i asystę przez całe życie dziecka, włącznie z dorosłością. W takim przypadku osiągnięcie dorosłości - podkreśla autor - będzie utrudnione nie tylko przez postawę rodziców, ale także przez oczekiwania społeczeństwa [Krause 2010, s. 122].

Reasumując, rodzina - podkreśla A. Krause "[d]la dużej części osób z niepełnosprawnością intelektualną (...) jest dobrym miejscem do mieszkania tylko do pewnego wieku. Pozostawanie $\mathrm{w}$ domu rodzinnym $\mathrm{w}$ dorosłości często pozbawia szans bycia w pełni dorosłym" [2016, s. 18]. Skutkuje to wówczas tym, że osoby niepełnosprawne dość często przyjmują postawę bierną, wycofaną i wyizolowaną z życia społecznego [Ostrowska 2003, s. 56-57]. Oznacza to brak kompetencji, dzięki którym radziłyby sobie z problemami, tak jak osoby dorosłe. Brak tych kompetencji skutkuje utrwalaniem postawy bezradności, braku decyzyjności i odpowiedzialności, a czasami wręcz przyjęcia postawy roszczeniowej osób niepełnosprawnych. A. Ostrowska mówi o zamkniętym kole: „naciski i oczekiwania osób niepełnosprawnych, nieprzekraczające spraw podstawowego zabezpieczenia społecznego, nie stymulują polityki społecznej do eksponowania i rozwijania działań związanych z innymi sferami życia, a dodatkowo przyczyniają się do tego, że postawy osób niepełnosprawnych są postrzegane jako "roszczeniowe«" [tamże, s. 56]. 


\section{Zastosowana metodologia}

Podjęte badania zostały osadzone w paradygmacie interpretatywnym, który został zbudowany "na podstawie innej niż pozytywistyczna - wiedzy, wychodzącej od fenomenologii, która umożliwiła zmianę przedmiotu badań i zmieniła optykę patrzenia badaczy na świat, uzasadniała formułowanie nowych problemów badawczych, pozwoliła uzasadnić zbędność hipotez badawczych w poznawaniu. Budowany na bazie hermeneutyki, która wskazała na ważność osobistych relacji badacza z badanym, uświadomiła tymczasowość wiedzy (koło hermeneutyczne), równoprawność wielości rozumień tego samego zjawiska wynikających z zanurzenia jednostki w jej dziejowości, przebytych doświadczeń, wskazała na interpretację - jako istotę rozumienia. Budowany na podstawie interakcjonizmu symbolicznego, wskazującego, że w człowieku mieści się zarówno to, co wspólne z innymi, jak i to, co specyficzne wyłącznie dla niego, że znaczenia, jakie ludzie nadają światu, są rezultatem społecznego konstruowania sensu, są społecznym uczeniem się, wymianą interakcyjną pomiędzy ludźmi zapośredniczoną przez symbole, co pozwala zrozumieć, $w$ jaki sposób człowiek jest zarówno kimś podobnym do innych, jak i kimś zupełnie odrębnym w swej jednostkowości" [Bauman 2010, s. 97-98]. Do tych trzech perspektyw: fenomenologii, hermeneutyki i interakcjonizmu symbolicznego odnosiłam się $w$ toku badań. W równym stopniu stanowiły one dla mnie inspirację, ponieważ celem było znalezienie we fragmentach rzeczywistości prezentowanych przez dorosłe osoby z niepełnosprawnością intelektualną, odpowiedzi na pytania, które były dla mnie znaczące.

Celem badawczym było poznanie i zrozumienie rzeczywistości kreowanej przez dorosłe osoby z niepełnosprawnością intelektualną w stopniu lekkim. Problem główny brzmiał: Jak interpretują swoją dorosłość osoby z niepełnosprawnością intelektualną mieszkające ze swoimi rodzicami? Interesowało mnie, jak badani realizują swoją dorosłość w środowisku rodzinnym, jak poprzez swoje mówienie definiują swoją dorosłość, jak jej doświadczają i jak ją konstruują, jakiego znaczenia jej nadają w kontekście niepełnosprawności, i co w ich perspektywie jest najważniejsze.

We współczesnej metodologii dominuje pogląd, że nie istnieją oczywiste metody badawcze. Toteż dobór metod powinien być uwarunkowany wyborem tematu i jego problematyką. Sugerując się tym, w swoich badaniach posługiwać się będę analizą biograficzną, sytuowaną w nurcie metodologii interpretatywnej. Wielu badaczy przyjmuje perspektywę biograficzną, gdzie przedmiotem zainteresowań badacza - pisze I. Lindyberg -jest "osobista prawda człowieka" [2003, s. 75]. Wykorzystanie tej metody pozwoliło mi, jak sądzę, dotrzeć do wiedzy „prawdziwej”, ponieważ w badaniach narracyjno-biograficznych chodzi o „ujęcie 
ludzkiego działania na tle warunków i okoliczności, w jakich przebiega życie danego człowieka, ujęcie tego działania wraz z jego sensem i znaczeniem" [Urbaniak-Zając 2005, s. 126]. Strategia biograficzna odwołuje się „zawsze do subiektywnej perspektywy badanych osób, czyniąc ich własny punkt widzenia niezbędnym punktem wyjścia do konstruowania uogólnień teoretycznych" [Włodarek, Ziółkowski 1990, s. 5]. Celem analizy biograficznej jest wydobycie subiektywnego sensu przeżyći doświadczeń badanych [Lalak 2010, s. 239], co implikuje wnikanie w biografie z perspektywy "subiektywnie” znaczącego doświadczenia [Denzin 1990, s. 68]. Autor tłumaczy, że badacz „musi wżyć się w biografię drugiej osoby tak, by móc spojrzeć na jej doświadczenie z podwójnej perspektywy, znajdować się tam gdzie ona, postrzegając i artykułując jej przeżycia oczyma i ustami" [tamże].

W następstwie zastosowania tej metody, możliwe było wykorzystanie analizy narracji. Narracja oparta na historiach ludzi - podkreśla Dorota Klus-Stańska jest ,jednym ze sposobów rozumienia świata przez ludzi". Autorka zaznacza, że narracja jest "sposobem naturalnym i koniecznym dla zrozumienia życia” (202, s. 111). Dokonując wyboru techniki badawczej przyświecały mi słowa Brunera, które zacytowała E. Kos: „(...) życie jednostki nie jest takie, jakie jest, ale takie, jak ona je opowiada i interpretuje (2013, s. 95). Inaczej mówiąc, narracja odsłania sposób rozumienia rzeczywistości przez jednostkę" [tamże].

Wywiady narracyjne zostały przeprowadzone z czterema dorosłymi kobietami $\mathrm{z}$ niepełnosprawnością intelektualną $\mathrm{w}$ stopniu lekkim. Rozmówczynie mieściły się w przedziale wiekowym od 30 do 41 lat i pochodzily z Olsztyna. Dwie z nich pracują na otwartym rynku pracy - Anna (41 lat), Ewelina (32 lata). Katarzyna (lat 36) pracowała, ale w wyniku redukcji etatów została zwolniona, na chwilę obecną pozostaje bez pracy. Wioletta (lat 30) nie pracuje i nigdy nie pracowała. Poszukiwałam dorosłych osób z lekką niepełnosprawnością intelektualną mieszkających ze swoimi rodzicami. Chciałam dowiedzieć się, jak osoby te, które często „wtapiają" się w życie społeczne, interpretują swoją dorosłość w kontekście wspólnego zamieszkania z rodzicami. Dobór próby był więc celowy, co jest typowe dla badań jakościowych. Z kobietami nawiązałam kontakt przez osoby trzecie. Przed przystąpieniem do transkrypcji wywiadów, spotykałam się wielokrotnie z badanymi. Spotkania odbywały się głównie w ich miejscu zamieszkania. Na spotkaniach tych poruszane były tematy pozwalające przełamać barierę wstydu i niepewności. Rozmowy oparte były na wzajemnym szacunku i zaufaniu oraz wzajemnym zaangażowaniu.

Wywiady przeprowadzono w okresie od stycznia do marca $2017 \mathrm{r}$. Nagrywano je na dyktafon, co pozwoliło uchwycić autentyczność języka respondentów oraz uczucia i emocje towarzyszące tym narracjom. Rozpoczynając wywiady prosiłam, aby badane opowiedziały mi swoją historię. Nagrane opowieści na bieżąco 
były przepisywane, aby w pełni uchwycić i oddać nie tylko treść narracji, lecz także zachowania niewerbalne badanych.

Przyjęte przez mnie podejście badawcze wymagało, aby w podjętych badaniach etap analityczny realizowany był równolegle do etapu zbierania danych. W fazie reprezentacji danych wykorzystałam analizę sekwencyjną, tzn. po rekonstrukcji kolejnych przestrzeni doświadczeń biograficznych i wydarzeń kluczowych, tekst został podzielony na sekcje opatrzone tytułami, które utworzyły sekwencje tematyczne. Porządkowanie materiału empirycznego nie zostało ustalone wcześniej tylko pojawiło się przy próbie strukturalizacji wypowiedzi badanych. Innymi słowy źródłem tych uporządkowań byli sami badani, ich inwencje, stworzone przez nich opowieści, a nie badacz.

\section{Analiza materiału badawczego}

Analizując materiał empiryczny można było dostrzec pewne elementy wspólne dla wszystkich narracji jak i te, które je od siebie odróżniały. Wyłonione kategorie odzwierciedlają doświadczenia i ukazują subiektywną prawdę, której rozmówczynie doświadczają. W opowieściach bardzo duży nacisk został położony na interpretowanie dorosłości, na podkreślanie jej atutów i kryteriów. Analiza narracji pokazuje, że dorosłość interpretowana jest przez narratorki podobnie jak przez osoby pełnosprawne. Dla moich rozmówczyń dorosłość wiąże się z podjęciem pracy, szeroko rozumianą samodzielnością i samostanowieniem, nawiązaniem intymnej relacji, zawarciem związku, założeniem rodziny, obowiązkami wynikającymi z utrzymania domu itp.:

„dorosłym się jest jak się ma rodzinę, chodzi się do pracy, bo ja chodzę do pracy. (...) no przecież jestem dorosła, sama zarabiam (....)". (Anna)

"(...) ludzie dorośli mieszkają sami i ja też będę tylko mama każe mi wszystko robić, bo muszę się wszystkiego nauczyć, mama mówi, że jak zostanę sama, to żebym sobie poradziła (...) jestem już dorosła, mam chłopaka, to sobie poradzę (...)". (Katarzyna)

"(...) Osoba dorosła sama za siebie decyduje, sama podejmuje różne decyzje (...), mam narzeczonego i też chcę mieć dziecko (...) sama wracam z pracy i sama przychodzę do domu, ale to nie jest taka fajna praca". (Ewelina)

„Mój starszy brat ma dziewczynę i oni się zamykają w pokoju jak ona przychodzi i ja też chcę mieć chłopaka, bo już jestem dorosła (...) mama mówi, że jeszcze nie mogę mieć chłopaka, ale ja chcę, (...) jestem już dorosła, ale jeszcze nie mogę sama mieszkać". (Wioletta)

Atrybutem dorosłości jest m.in. samodzielność, decyzyjność i samostanowienie. Dla moich rozmówczyń kategorie te są bardzo istotne i nabierają ogromnego 
znaczenia w ich codziennym funkcjonowaniu. Dorosłość narratorek jest jednak bardzo ograniczana przez rodziców, co stanowi dla nich duży dyskomfort i zakłopotanie. Rozmówczynie inaczej wyobrażają sobie swoją dorosłość, niż jej doświadczają. Mają świadomość tego, że są ograniczane przez rodziców z powodu niepełnosprawności, która $\mathrm{w}$ ich odczucia nie zabrania im normalnie żyć:

„jestem zła nieraz na mamę bo ona nie pozwala mi iść do mojego chłopaka. Jestem niepełnosprawna, ale mogę chyba się z nim spotkać, (...) bo ja nie czuję tego, że jestem niepełnosprawna i chcę żyć normalnie". (Katarzyna)

"Chciałabym żyć, tak sama o wszystkim decydować, a nie, nie rób tego, nie rób tamtego, jakbym była dzieckiem. Czasami nawet mama próbuje mnie ubierać jakbym była małą dziewczynką". (Wioletta)

„Sama robię zakupy, chodzę do pracy, w pracy też wszystko robię sama, nikt mi nie pomaga. (...) chciałabym mieszkać sama ale mama mówi, że za mało zarabiam (...) niby jestem dorosła, a nie mogę sama decydować o wszystkim". (Ewelina)

„Nie rozumiem dlaczego niepełnosprawni nie mogą wielu rzeczy robić. Przecież my też chcemy realizować swoje marzenia (...)". (Anna)

Podjęcie pracy bez wapienia jest dla narratorek oznaką dorosłości. Rozmówczynie nadały temu wydarzeniu ogromne znaczenie. $Z$ narracji można wnioskować, że to praca i posiadanie wynagrodzenia stanowi największy krok ku samodzielności i niezależności, a w konsekwencji ku dorosłości. Rozmówczynie, które pracują są bardzo dumne z posiadania pracy i z otrzymywanego wynagrodzenia, relacji z kolegami/koleżankami z pracy, nabyciu wielu umiejętności itp. Kobiety nieposiadające pracy, także chciałyby pracować, ponieważ z pracą utożsamiają daleko idącą autonomię. $\mathrm{W}$ ich odczuciu posiadanie pracy i wynagrodzenia dałoby im samodzielność $w$ podejmowaniu decyzji, niezależność finansową. Ponadto praca w odczuciu narratorek stanowi kryterium normalności. Wszyscy pracują, więc i badane, które często $\mathrm{w}$ opowieściach podkreślały swoją normalność, także chciałyby pracować, aby móc się wpisać w tę kategorię. Niepracujące narratorki, bardzo ubolewają nad swoją sytuacją i mają świadomość zależności od rodziców z tego powodu. Taki stan nie jest dla kobiet komfortowy i zaniża ich poczucie wartości:

"(...) chodzę do pracy, w pracy też wszystko robię sama, nikt mi nie pomaga (...) jakbym miała więcej pieniędzy, to mogłabym zamieszkać sama". (Ewelina)

„Dorosłym się jest jak chodzi się do pracy, bo ja chodzę do pracy. (...) lubię dostawać wypłatę, wtedy mogę kupić co chcę (...) i dużo się tam nauczyłam. Teraz w domu już sama piekę ciasta, ciasteczka (...)". (Anna)

„Nie pracuję, no bo nie mam pracy (...) Nie czuję tego, że jestem niepełnosprawna i chcę robić to co inni. (...) Mam swoje zainteresowania. Lubię robić taką biżuterię, bo my z mamą taką robimy i wszyscy moi znajomi mówią, że mogłabym robić i inne rzeczy, bo jestem zdolna. Chciałabym tak normalnie pracować i mieć wypłatę. Chciałabym sama 
decydować, na co wydać te pieniądze, bo tak to o wszystko muszę prosić rodziców, a to tak wygląda jakbym ciągle była dzieckiem”. (Katarzyna)

„(...) kiedyś pracowałam i było fajnie, bo zarabiałam ale później umowa się skończyła i nie ma pracy. (...) Ja chciałabym pracować, bo jestem pracowita. Źle mi bez pracy, bo moi znajomi pracują i mają własne pieniądze, a ja tylko gapię się w telewizor i nic. (...) może dlatego nie mam pracy bo jestem niepełnosprawna? Nie wiem". (Wioletta)

W funkcjonowaniu osób o niepełnej sprawności intelektualnej ograniczenia i bariery występują w każdej płaszczyźnie ich życia. Z opowieści wynika, że narratorki doświadczają tych ograniczeń także w środowisku rodzinnym, gdzie rodzice i inni członkowie rodziny wykazują się zbytnią troską i nadopiekuńczością. W narracji rozmówczyń słychać żal i rozgoryczenie z powodu takiego podejścia, które - jak podkreślają badane - ogranicza ich dorosłość i hamuje wszelką samodzielność. Rozmówczynie tym ograniczeniom nadają ogromne znaczenie, ponieważ to przez nie czują się niepełnosprawne. Nie doświadczają następstw niepełnosprawności, natomiast nadmierna kontrola powoduje, że nie czują się dorosłe:

„Mama to uważa, że chyba nadal jestem dzieckiem, martwi się o mnie bo jestem niepełnosprawna, ale już nie jestem dzieckiem". (Wioletta)

"(...) siostra załatwiła mi pracę u siebie, to znaczy w piekarni, (...) nie chcę z nią pracować, bo ona mnie wciąż poucza". (Anna)

„Oni nie rozumieją, że to mnie ogranicza, że jak będą mnie tak kontrolować, to ja nigdy nie zrobię tego czy tamtego, bo zawsze rodzice". (Ewelina)

„czasami jak mówię, że idę do Jacka (chłopak - uzup. I.M) to w domu się mnie pytają, co będziemy robić, gdzie iść i takie tam (...) ja wiem jak zachodzi się w ciążę, bo w szkole mieliśmy takie zajęcia i ja jeszcze nie chcę mieć dzieci". (Katarzyna)

Najwięcej ograniczeń występuje w środowisku rodzinnym. Narratorki podkreślają na każdym etapie narracji, że są świadome swojej niepełnosprawności, ale zaznaczają również swoją samodzielność. Rozmówczynie wspominają o dużej swobodzie i niezależności w murach domu, natomiast wszelkie przejawy samodzielności poza domem są przez rodziców kontrolowane, a niekiedy wręcz tłumione. Tak jest w przypadku relacji z innymi, w zakresie spędzania czasu wolnego czy nawet w przypadku podjęcia pracy.

Analiza narracji pokazuje, że rozmówczynie dużą wagę przywiązują do relacji. Są bardzo serdeczne, ciepłe i otwarte na nowe znajomości, a posiadanie koleżanki czy przyjaciółki daje poczucie bycia potrzebną i ważną, ale przede wszystkim jest oznaką normalności. Relacje z innymi są dla kobiet źródłem wielu radości, ale z powodu dużego zaangażowania rodziców w te relacje, stają się również powodem rozgoryczenia: 
„(...) Mam swoją koleżankę (...) dzwonimy do siebie, ja lubię chodzić do niej, ona do mnie też lubi chodzić (...) mama nie lubi jak sama gdzieś idę, wtedy cały czas dzwoni do mnie". (Wioletta)

"(...) spotykamy się ze znajomymi i sobie gdzieś idziemy, tak jak normalnie ludzie gdzieś chodzą (...). Kiedyś zostałam u koleżanki na noc, to była taka awantura w domu i już więcej nie zostaję". (Anna)

„Z Magdą (przyjaciółką - uzup. I.M.) rozumiemy się bez słów. Ona tak jak ja jest niepełnosprawna, ale ona ma rozszczep kręgosłupa". (Ewelina)

„Ludzie myślą, że niepełnosprawni to nie mają kolegów czy znajomych i to mnie wkurza, bo my chcemy normalnie żyć i spotykać się ze znajomymi, tak jak wszyscy". (Katarzyna)

Poza relacjami koleżeńskimi bardzo ważne dla narratorek są relacje intymne. Trzy rozmówczynie mają stałych partnerów i jak same podkreślają, mają nadzieję na zawarcie małżeństwa i założenie rodziny. Te fragmenty narracji wywołują wielką radość u kobiet. W swoich działaniach i marzeniach są jednak ograniczane przez rodziców, których intencji nie rozumieją. W ich odczuciu normalne jest, że dorosłe osoby nawiązują bliskie relacje, które w przyszłości mogą zaowocować związkiem małżeńskim i założeniem rodziny. Odnoszę wrażenie, iż seksualność tych kobiet $\mathrm{i}$ ich potrzeby w tym zakresie są przez rodziców traktowane dość marginalnie. Narratorki mają tego świadomość, dlatego podnoszą kwestię swojego wieku i samodzielnie funkcjonujących koleżanek:

„(...) wszystkiego będę uczyć swoje dzieci, (...) mam narzeczonego i chcę mieć dziecko $(\ldots)^{\prime \prime}$. (Anna)

„Mam narzeczonego. On nawet chce się ze mną ożenić, ale mama powiedziała, że mieszkam razem z nią i koniec. Nie rozumiem czemu niepełnosprawni muszą mieszkać z rodzicami? Przecież nie jestem głupia i wiem co trzeba robić w domu. Mam 32 lata i chcę sama o sobie decydować". (Ewelina)

„Mój starszy brat ma dziewczynę i ja też chcę mieć chłopaka, bo już jestem dorosła (...) mama mówi, że jeszcze nie mogę mieć chłopaka, ale ja chcę, moja koleżanka już ma i lubi trzymać swojego chłopaka za rękę, ja też chcę". (Wioletta)

„To chyba normalne, że chcę mieć męża i rodzinę. Teraz jeszcze nie, bo nie mam pracy, bo trzeba z czegoś żyć. Mam już swoje lata a nadal mieszkam z rodzicami (...) koleżanki w moim wieku już mają dzieci (...)". (Katarzyna)

W realizowaniu dorosłości ważną kategorią staje się także czas wolny, który jest ważnym elementem w codziennym funkcjonowaniu. Nabiera on szczególnego znaczenia dla kobiet, ponieważ daje im poczucie normalnego życia. Narratorki w swoich opowieściach podkreślają dość często, że chcą żyć normalnie. Czas spędzony w gronie znajomych, samodzielnie zaplanowany i spędzony, realizowanie swoich pasji i zainteresowań jest dla młodych kobiet bardzo ważny. Te fragmenty narracji są bardzo radosne, a narratorki często przywołują mile wspomnienia. 
Warto jednak zauważyć, że w tej kwestii także uwidacznia się kontrola rodziców, co bardzo ogranicza dorosłość i irytuje rozmówczynie:

„My z moich chłopakiem chodzimy na lody do kawiarni, do kina, na spacer. Robimy to co wszyscy inni ludzie. Chciałabym pojechać nad morze. Lubię wodę (...) denerwują mnie tylko pytania mamy, bo ona wszystko musi wiedzieć". (Katarzyna)

(...) spotykam się z ludźmi na mieście, chodzimy do kina albo na spacer, robimy różne rzeczy. Siostra wychodzi z domu i nikomu się nie tłumaczy, a ja muszę". (Anna)

„Nie czuję tego, że jestem niepełnosprawna i chcę robić to co inni. (...) mam swoje zainteresowania. Lubię robić taką biżuterię, bo my z mamą taką robimy i wszyscy moi znajomi mówią, że mogłabym robić i inne rzeczy bo jestem zdolna". (Katarzyna).

„Lubię chodzić do kina. Mój narzeczony często mnie zabiera (...) nie lubię tylko filmów z napisami bo nie umiem szybko czytać, ale lubię polskie komedie albo jakieś romanse (...) i lubię słuchać muzyki takiej spokojnej. (...) muszę powiedzieć, o której wrócę do domu, a jak się spóźniam to od razu mam telefon". (Ewelina)

Posiadanie pieniędzy daję swobodę w organizacji czasu wolnego. Moje rozmówczynie bardzo chętnie udzielają się towarzysko, są otwarte i bardzo radosne. Posiadanie znajomych ma dla nich ogromne znaczenie. Realizują w ten sposób potrzebę przynależności i akceptacji. Narratorki często podkreślają, iż nie czują się niepełnosprawne, a co za tym idzie, chciałyby mieć znajomych, realizować zainteresowania i pasje. Także $w$ tym przypadku odnoszą się do kryterium normalności, jednak ta sfera nie jest taka, jak w przypadku osób pełnosprawnych. Rodzice kontrolują czas wolny, ingerują w relacje koleżeńskie i związki z partnerami. Taka postawa rodziców jest dla narratorek bardzo krzywdząca, bowiem sami rodzice traktują dorosłe już kobiety jak dzieci.

Z opowieści można wnioskować, że miłość rodziców skutkuje nadmierną troską i opieką wobec dorosłych już kobiet. Postawa rodziców podyktowana jest być może podejściem społeczeństwa do osób o niepełnej sprawności intelektualnej i świadomością deficytów wynikających z braku normy intelektualnej. Narratorki często podkreślają, jak są poirytowane, rozżalone postawą rodziców wobec nich, ale zaznaczyć także należy, że rozmówczynie zawsze $\mathbf{w}$ rodzicach mają ogromne wsparcie i pomoc. W swoich opowieściach wracają do przeszłości, ale także nawiązują do czasu obecnego, gdzie rodzice niezależnie od sytuacji i problemu zawsze przy nich są. Dla moich rozmówczyń były to ważne fragmenty w ich narracjach, którym towarzyszyły łzy i chwile zadumy:

„mam bardzo duże wsparcie w moich rodzicach, nieraz jak ktoś mi zrobił przykrość i płakałam to rodzice mi mówili, żebym się nimi nie przejmowała, bo i tak jestem wyjątkowa a oni mnie taką kochają (łzy)". (Ewelina)

„inne dzieci kiedyś dokuczały mi, ale mama zawsze była po mojej stronie i było mi lepiej (...) przytulała mnie i głaskała mnie po głowie". (Wioletta) 
„jak nie mogłam znaleźć pracy, to mama mówiła wtedy, żebym się nie martwiła, bo będziemy dotąd szukać, aż ją znajdziemy. (...) potem znalazłam pracę". (Anna)

„mój pierwszy chłopak mnie rzucił jak dowiedział się, że mam orzeczenie. (...) przyszła mama i powiedziała, że niedługo na pewno będę miała drugiego chłopka. (...) i teraz jest Adam, który mnie bardzo kocha". (Katarzyna)

\section{Podsumowanie}

Funkcjonowanie dorosłych osób z niepełnosprawnością intelektualną cały czas podlega ocenie i wymaganiom społeczeństwa, które nie jest przychylne wobec tej grupy osób. Widoczne jest w licznych barierach tworzonych przez osoby pełnosprawne. W takiej sytuacji oczekiwać by można, iż środowisko rodzinne będzie tym, które odpowiednio ukształtuje tożsamość osoby niepełnosprawnej, zbuduje jej poczucie wartości, zaspokoi potrzeby m.in. miłości, akceptacji i przynależności, przygotuje i pomoże $\mathrm{w}$ pokonywaniu barier, a także wprowadzi w dorosłe, samodzielne życie.

Z analizy narracji wyłania się dorosłość doświadczana przez osoby o niepełnej sprawności intelektualnej. Dorosłe kobiety, nadal mieszkające z rodzicami, interpretują ten etap rozwoju bardzo subiektywnie, rekonstruując wydarzenia bardziej lub mniej znaczące w ich życiu. Narratorki są świadome atrybutów dorosłości, do których realizacji dążą. Nadają wielkie znaczenie takim kategoriom takim jak praca, samodzielność, niezależność finansowa, założenie rodziny itp. Dorosłość interpretowana jest przez kobiety podobnie jak przez osoby pełnosprawne, toteż w swoich opowieściach podkreślają znacząco, że dążą do tego, aby „żyć normalnie". Być może dlatego tak wielką wagę przywiązują do szeroko pojętej samodzielności, niezależności i autonomii. Jakiekolwiek próby ograniczenia tej wolności wywołują u rozmówczyń negatywne emocje. Kobiety nie mają problemów z werbalizowaniem swoich odczuć i potrzeb, ale - jak wynika z analizy narracji - potrzeby te dość często są lekceważone przez rodziców, niezależnie jakiej płaszczyzny dotyczą.

Z opowieści wyłania się dorosłość, która z powodu nadmiernej troski, kontroli i ograniczeń ze strony rodziców zostaje zakłócona. Narratorki respektują te wszelkie nakazy i zakazy, ale nie zgadzają się z nimi, ponieważ inaczej wyobrażają sobie swoją dorosłość. Bardzo są świadome swojej niepełnosprawności, ale podkreślają także, że nie jest to powód, aby były dyskredytowane $\mathrm{w}$ jakiejkolwiek płaszczyźnie życia społecznego, szczególnie przez najbliższe im osoby. Rodzice traktują narratorki jak małe dzieci, które trzeba pouczać, strofować, prowadzić za rękę i podejmować za nie decyzje. Kobiety nie rozumieją zachowań rodziców, bowiem uważają, że niepełnosprawność, którą zostały dotknięte nie ogranicza ich 
w działaniu, myśleniu i wzięciu odpowiedzialności za siebie. Można wnioskować, że postawa rodziców wynika z faktu, iż musieli oni niejednokrotnie zmierzyć się z wieloma problemami we wcześniejszych etapach życia ich dzieci. Świadomość ograniczeń będących następstwem niepełnosprawności i ciągła odpowiedzialność, może skutkować zaburzonym postrzeganiem dziecka, przyjęciem niewłaściwej postawy, czy nadmiernym zaangażowaniem.

Konkludując tak narracje kobiet, jak i moje rozważania, warto podkreślić, iż rodzice muszą sobie uzmysłowić, że zmiana w ich sposobie myślenia i działania wobec dorosłych dzieci może zaowocować samodzielnością życiową, jak i szczęściem z doświadczania wszelkich przejawów dorosłości. Narratorki marzą o samodzielnym zamieszkaniu, o zawarciu małżeństwa i posiadaniu potomstwa, o pracy, która dałaby im samodzielność finansową. Te i wiele innych aspektów nie zyskuje aprobaty rodziców, którzy z troski nadal chcą kierować życiem dorosłych już dzieci. Rodzice nie zdają sobie sprawy z krzywdy, którą wyrządzają i z tego, że to ich postawa i zachowanie wobec kobiet czyni je bardziej niepełnosprawnymi, niż niepełnosprawność, którą zostały dotknięte. Dochodzi wówczas do „wtórnego upośledzenia i ograniczania autonomii osoby z niepełnosprawnością" [Żyta 2010, s. 96].

\section{Bibliografia}

Bauman T. (2010), Poznawczy status danych jakościowych [w:] Metodologiczne problemy tworzenia wiedzy w pedagogice. Oblicza akademickiej praktyki, J. Piekarski, D. Urbaniak-Zając, K.J. Szmidt (red.), Oficyna Wydawnicza „Impuls”, Kraków.

Brzezińska A., Appelt K., Ziółkowska B. (2008), Psychologia rozwoju człowieka [w:] Psychologia. Podręcznikakademicki, J. Strelau, D. Doliński (red.), Gdańskie Wydawnictwo Psychologiczne, Gdańsk.

Borowska-Beszta B. (2012), Niepetnosprawność w kontekstach kulturowych i teoretycznych, Oficyna Wydawnicza „Impuls”, Kraków.

Czerwińska-Jasiewicz M. (2015), Psychologia rozwoju młodzieży w kontekście biegu ludzkiego życia, Wydawnictwo Difin, Warszawa.

Cytowska B. (2012), Trudne drogi adaptacji. Watki emancypacyjne w analizie sytuacji dorostych osób z niepetnosprawnościa intelektualnq we wspótczesnym społeczeństwie polskim, Oficyna Wydawnicza „Impuls”, Kraków.

Denzin N.K. (1990), Reinterpretacja metody biograficznej, [w:] Metoda biograficzna w socjologii, J. Włodarek, M. Ziółkowski (red.), Państwowe Wydawnictwo Naukowe, WarszawaPoznań.

Garlej-Drzewiecka E. (2003), Z rozważań o dorosłości [w: ] Dorostość, niepetnosprawność, czas wspótczesny. Na pograniczach pedagogiki specjalnej, K.D. Rzedzicka, A. Kobylańska (red.), Oficyna Wydawnicza „Impuls”, Kraków.

Gurba E. (2011), Wczesna dorostość, [w:] Psychologia rozwoju człowieka, J. Trempała (red.), PWN, Warszawa. 
Klus-Stańska D. (2002), Narracja w badaniu i kształceniu nauczycieli, „Forum Oświatowe”, s. 111.

Kos E. (2013), Wywiad narracyjny jako metoda badań empirycznych [w:] Badania jakościowe w pedagogice, D. Urbaniak-Zając, E. Kos, Wydawnictwo Naukowe PWN, Warszawa.

Krause A. (2010), Wspótczesne paradygmaty pedagogiki specjalnej, Oficyna Wydawnicza „Impuls", Kraków.

Krause A., Żyta A., Nosarzewska S. (2010), Normalizacja środowiska społecznego osób z niepetnosprawnościq intelektualna, Wydawnictwo Edukacyjne Akapit, Torun.

Krause A. (2016), Dorosłość w niepetnosprawności intelektualnej, „Niepełnosprawność”, nr 24.

Lalak D. (2010), Życie jako biografia. Podejście biograficzne w perspektywie pedagogicznej, Wydawnictwo Akademickie „Żak”, Warszawa.

Lindyberg I. (2003), Biograficzne odtwarzanie rzeczywistości a hermeneutyczne podejście do badań w pedagogice specjalnej, [w:] Konteksty teoretyczne, A. Krause, E. Garniewicz (red.), Wydawnictwo UWM, Olsztyn.

Pichalski R. (2003), Refleksje nad dorostościa [w:] Dorostość, niepetnosprawność, czas wspótczesny. Na pograniczach pedagogiki specjalnej, K.D. Rzedziecka, A. Kobylańska (red.), Oficyna Wydawnicza „Impuls”, Kraków.

Smykowski B. (2004), Wczesna dorostość, „Remedium” nr 2 (132), s. 4-5.

Tyszkowa M. (1980), Rozwój człowieka dorosłego w świetle wybranych koncepcji teoretycznych psychologii, „Oświata Dorosłych” nr 2, s. 65-73.

Włodarek J., Ziółkowski M. (red.) (1990), Metoda biograficzna w socjologii, Państwowe Wydawnictwo Naukowe, Warszawa-Poznań.

Żółkowska T. (2003), Wartościowanie pojęcia "dorosłość" przez osoby niepetnosprawne intelektualnie [w:] Dorosłość, niepetnosprawność, czas wspótczesny. Na pograniczach pedagogiki specjalnej, K.D. Rzedzicka, A. Kobylańska (red.), Oficyna Wydawnicza „Impuls”, Kraków.

Żyta A. (2010), Rodzina jako miejsce stymulacji w doświadczaniu świata [w:] Normalizacja środowiska społecznego osób z niepetnosprawnością intelektualną, A. Krause, A. Żyta, S. Nosarzewska, Wydawnictwo Edukacyjne Akapit, Torun. 